EDITORIAL

\title{
Immune checkpoint inhibitors and allogeneic transplant in lymphoid malignancies: a deceptive friend story
}

๑ The Author(s), under exclusive licence to Springer Nature Limited 2021, corrected publication 2022

Bone Marrow Transplantation (2021) 56:2624-2625; https://doi.org/10.1038/s41409-021-01396-6

A major breakthrough in the treatment of classical Hodgkin's lymphoma ( $\mathrm{CHL}$ ) and other lymphoid malignancies, mainly primary mediastinal B cell lymphoma was the efficacy of checkpoint inhibitors (CPIs) in the relapsed and/or refractory (R/R) setting, including those relapsed post autologous stem cell transplantation [1-3]. In CHL, the Reed-Sternberg malignant cells usually compose a small fraction of the tumor bulk, attracting a wide and complex microenvironment supporting its survival by a constant activation of the programmed death protein -1 (PD-1) pathway among others [4]. This uniqueness in the tumor structure and biology translated into a true therapeutic success through PD-1 blockage by either nivolumab or pembrolizumab. The disruption of the immune evasion process by CPIs leeds to the elimination of malignant cells, and durable responses in a subset of patients in multiple clinical trials $[1,2]$.

Despite observed prolonged duration of response after CPIs treatment, patients still relapse, and allogeneic stem cell transplantation (alloSCT) remain the only potential curative intent in patients with $\mathrm{R} / \mathrm{R} \mathrm{cHL}$ given the graft versus lymphoma effect [5]. Soon after the introduction of CPIs treatment as a bridge to alloSCT, many reports emerged related to increased risk of fatal hyper-acute graft-versus-host disease (GVHD), non-infectious febrile episodes requiring corticosteroids, and other immunerelated adverse events [6-8]. Based on these observations, the US Food and Drug Administration issued a "warning and precaution" regarding the potential life-threatening immune-related complications with the use of nivolumab or pembrolizumab in the perialloSCT period. The effect of CPIs on the T-cell activation and their long half-life might have affected post- alloSCT outcomes and increased the non-relapse mortality, posing a real challenge to clinicians to find a better way for a safer alloSCT procedure post CPIs treatment.

A better understanding of the underlying biologic features of $\mathrm{CHL}$, the basis of CPIs responsiveness, and the recent developments in the alloSCT procedure, particularly the introduction of post-transplant cyclophosphamide (PTCy) as GVHD prophylaxis, rendered the use of CPIs before and/or after alloSCT more feasible [9].

Bobillo et al. eloquently reviewed the available clinical data regarding the use of $\mathrm{CPI}$ in lymphoid malignancies treated with alloSCT, and highlighted several clinically relevant practices to carry on a safer alloSCT procedure [10]. In their review article, they described the lingering effect of PD-1 blockade following alloSCT, where residual PD-1 antibodies are capable of activating the allogeneic donor-derived T cells, exerting a graft-versus-lymphoma effect, thus the reduced risk of relapse. In spite of that, activated alloreactive $T$ cells would also recognize recipient normal cells of the skin, gut, and liver causing tissue damage and acute GVHD. Despite the scarcity of clinical trials, there are emerging findings through retrospective series endorsing the use of PTCy to abrogate the effect of the activating alloreactive T cells and to restore the regulatory and effector T-cell homeostasis, consequently reducing the incidence of severe GVHD [11, 12].

Other therapeutic strategy discussed in this review was holding CPI at least 6 weeks before alloSCT to be able to wash out the PD1 antibodies. Although it is theoretically plausible, but neither the time from CPI to transplant nor the number of doses used before alloSCT proved to be an adverse risk factor for post-alloSCT complications [13, 14].

Similarly, the use of CPIs after alloSCT relapse can be effective, but with increased GVHD-related morbidity and mortality. Due to limited data, there is need for extreme caution while making decisions regarding the use of CPIs after alloSCT, especially in patients with history of prior GVHD, or relapsing within 180 days from alloSCT. Once used, it is advisable to start with a low dose and gradually escalate if no response or toxicity were seen [13]. Some studies of CPIs before and after allo-HSCT are listed in Table 1.

Further prospective studies are definitely needed to answer many questions related to the feasibility and optimal timing of alloSCT in the era of CPI treatment. Whether alloSCT is still a needed step for long-term survival is an ongoing debate, knowing that during the long-term follow-up of single agent CPI treatment in heavily pre-treated $\mathrm{cHL}$, there was a subset of patients that continued to respond beyond 3 years despite stopping the treatment [15]. It is therefore worth investigating which subset of patients might be cured from CPI treatment alone, without the need of alloSCT.

Mohammed Al Farttoosi ${ }^{1}$ and Jean El Cheikh ${ }^{2}{ }^{\text {物 }}$ ${ }^{1}$ College of Medicine, University of Basrah, Basrah, Iraq. ${ }^{2}$ Bone Marrow Transplantation Program and Division of Hematology and Oncology, Department of Internal Medicine, American University of Beirut, Beirut,

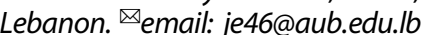


Table 1. Some studies of checkpoint inhibitors before and after allo-HSCT.

\begin{tabular}{|c|c|c|c|c|c|c|c|c|}
\hline $\begin{array}{l}\text { Timing in relation } \\
\text { to allo-HSCT }\end{array}$ & Drugs in use & $\begin{array}{l}\text { Total number } \\
\text { of cases }\end{array}$ & Disease & a-GVHD & C-GVHD & NRM & PFS/OS & Reference \\
\hline Pre- & Nivolumab & 15 & $\mathrm{HL}$ & $3 / 15$ & $3 / 15$ & $1 / 15$ & $-1-$ & Bekoz et al. [17] \\
\hline Pre- & Nivolumab & 209 & $\mathrm{HL}$ & $\begin{array}{l}15 \% \text { ( } 180 \text { days) } \\
\text { Grade } 3-4\end{array}$ & $34 \%$ & $14 \%$ (2 years) & $\begin{array}{l}69 \% / 82 \% \\
(2 \text { years })\end{array}$ & $\begin{array}{l}\text { Merryman et al. } \\
\text { [14] }\end{array}$ \\
\hline Post- & Nivolumab & 20 & $\mathrm{HL}$ & - & $5 / 20$ & $2 / 20$ & $-1-$ & $\begin{array}{l}\text { Herbaux et al. } \\
\text { [13] }\end{array}$ \\
\hline Post- & $\begin{array}{l}\text { Nivolumab } \\
\text { pembrolizumab }\end{array}$ & 31 & $\mathrm{HL} / \mathrm{NHL}$ & $32 \%$ & $7 \%$ & $5 / 17$ & $-1-$ & $\begin{array}{l}\text { Harvekos et al. } \\
\text { [7] }\end{array}$ \\
\hline
\end{tabular}

HL Hodgkin's Lymphoma, NHL Non-Hodgkin Lymphoma, a GVHD acute graft-versus-host disease, c GVHD chronic graft-versus host disease, NRM non-relapse mortality, PFS progression free survival, OS overall survival.

\section{REFERENCES}

1. Armand P, Shipp MA, Ribrag V, Michot JM, Zinzani PL, Kuruvilla J. et al. Programmed death-1 blockade with pembrolizumab in patients with classical Hodgkin lymphoma after brentuximab vedotin failure. J Clin Oncol. 2016:34:3733-9. https://doi.org/10.1200/jco.2016.67.3467.

2. Younes A, Santoro A, Shipp M, Zinzani PL, Timmerman JM, Ansell S. et al. Nivolumab for classical Hodgkin's lymphoma after failure of both autologous stemcell transplantation and brentuximab vedotin: a multicentre, multicohort, singlearm phase 2 trial. Lancet Oncol. 2016;17:1283-94. https://doi.org/10.1016/s14702045(16)30167-x.

3. Armand P, Rodig S, Melnichenko V, Thieblemont C, Bouabdallah K, Tumyan G. et al. Pembrolizumab in relapsed or refractory primary mediastinal large B-cell lymphoma. J Clin Oncol. 2019;37:3291-9. https://doi.org/10.1200/jco.19.01389.

4. Weniger MA, Küppers R. Molecular biology of Hodgkin lymphoma. Leukemia. 2021;35:968-81. https://doi.org/10.1038/s41375-021-01204-6.

5. Rashidi A, Ebadi M, Cashen AF. Allogeneic hematopoietic stem cell transplantation in Hodgkin lymphoma: a systematic review and meta-analysis. Bone Marrow Transpl. 2016;51:521-8. https://doi.org/10.1038/bmt.2015.332.

6. El Cheikh J, Massoud R, Abudalle I, Haffar B, Mahfouz R, Kharfan-Dabaja MA. et al. Nivolumab salvage therapy before or after allogeneic stem cell transplantation in Hodgkin lymphoma. Bone Marrow Transpl. 2017;52:1074-7. https://doi.org/ 10.1038/bmt.2017.69.

7. Haverkos BM, Abbott D, Hamadani M, Armand P, Flowers ME, Merryman R. et al. PD-1 blockade for relapsed lymphoma post-allogeneic hematopoietic cell transplant: high response rate but frequent GVHD. Blood. 2017;130:221-8. https://doi.org/10.1182/blood-2017-01-761346.

8. Armand P, Zinzani PL, Collins GP, Cohen JB, Halwani AS, Carlo-Stella C. et al. Outcomes of allogeneic hematopoietic stem cell transplantation (HSCT) after treatment with nivolumab for relapsed/refractory Hodgkin lymphoma. Blood. 2016;128:3502-3502. https://doi.org/10.1182/blood.V128.22.3502.3502.

9. Luznik L, O'Donnell PV, Fuchs EJ. Post-transplantation cyclophosphamide for tolerance induction in HLA-haploidentical bone marrow transplantation. Semin Oncol. 2012;39:683-93. https://doi.org/10.1053/j.seminoncol.2012.09.005.

10. Bobillo S, Nieto JC, Barba P Use of checkpoint inhibitors in patients with lymphoid malignancies receiving allogeneic cell transplantation: a review. Bone Marrow Transplant. 2021. https://doi.org/10.1038/s41409-021-01268-z

11. Paul S, Zahurak M, Luznik L, Ambinder RF, Fuchs EJ, Bolaños-Meade J. et al. Nonmyeloablative allogeneic transplantation with post-transplant cyclophosphamide after immune checkpoint inhibition for classic Hodgkin lymphoma: a retrospective cohort study. Biol Blood Marrow Transplant. 2020;26:1679-88. https:// doi.org/10.1016/j.bbmt.2020.06.012.
12. Schoch LK, Cooke KR, Wagner-Johnston ND, Gojo I, Swinnen L, Imus P. et al. Immune checkpoint inhibitors as a bridge to allogeneic transplantation with posttransplant cyclophosphamide. Blood Adv. 2018;2:2226-9. https://doi.org/ 10.1182/bloodadvances.2018019208.

13. Herbaux C, Merryman R, Devine S, Armand P, Houot R, Morschhauser F. et al. Recommendations for managing PD-1 blockade in the context of allogeneic HCT in Hodgkin lymphoma: taming a necessary evil. Blood. 2018;132:9-16. https://doi. org/10.1182/blood-2018-02-811174.

14. Merryman RW, Castagna L, Giordano L, Ho VT, Corradini P, Guidetti A, et al. Allogeneic transplantation after PD-1 blockade for classic Hodgkin lymphoma. Leukemia. 2021. https://doi.org/10.1038/s41375-021-01193-6.

15. Chen R, Zinzani PL, Lee HJ, Armand P, Johnson NA, Brice P. et al. Pembrolizumab in relapsed or refractory Hodgkin lymphoma: 2-year follow-up of KEYNOTE-087. Blood. 2019;134:1144-53. https://doi.org/10.1182/blood.2019000324.

16. Martínez C, Carpio C, Heras I, Ríos-Herranz E, Buch J, Gutierrez A, et al. Potential survival benefit for patients receiving allogeneic hematopoietic stem cell transplantation after nivolumab therapy for relapse/refractory Hodgkin lymphoma: Real-life experience in Spain. Biol Blood Marrow Transplant. 2020;26:1534-42.

17. Bekoz H, Karadurmus N, Paydas S, Turker A, Toptas T, Firatli Tuglular T, et al. Nivolumab for relapsed or refractory Hodgkin lymphoma: real-life experience. Ann Oncol. 2017;28:2496-2502. https://doi.org/10.1093/annonc/mdx341.

18. Ito A, Kim SW, Matsuoka KI, Kawakita T, Tanaka T, Inamoto Y, et al. Safety and efficacy of anti-programmed cell death-1 monoclonal antibodies before and after allogeneic hematopoietic cell transplantation for relapsed or refractory Hodgkin lymphoma: a multicenter retrospective study. Int J Hematol. 2020;112:674-689. https://doi.org/10.1007/s12185-020-02960-4.

\section{COMPETING INTERESTS}

The authors declare no competing interests.

\section{ADDITIONAL INFORMATION}

Correspondence and requests for materials should be addressed to J.E.C.

Reprints and permission information is available at http://www.nature.com/ reprints

Publisher's note Springer Nature remains neutral with regard to jurisdictional claims in published maps and institutional affiliations. 